\title{
Survival and agronomic performance of 25 alfalfa cultivars and strains interseeded into rangeland
}

\author{
J.D. BERDAHL, A.C. WILTON, AND A.B. FRANK
}

\begin{abstract}
This study assesses survival and agronomic performance of 7 year-old stands of 25 alfalfa (Medicago sativa $L$.) cultivars and experimental strains interseeded into rangeland near Mandan, N.Dak. Associated grasses consisted primarily of crested wheatgrass [Agropyron desertorum (Link) Schulte.], western wheatgrass [Pascopyrum smithii (Rydb.) Löve], needle-and-thread (Stipa comata Trin. \& Rupr.), and blue grama [Bouteloua gracilis (H.B.K.) Lag.]. Soil was a Chama silt loam (Typic Haplustolls), an upland soil with moderate water holding capacity. Each entry was replicated 4 times in a randomized complete block design in plots consisting of 3 interseeded rows $6.1 \mathrm{~m}$ long with $90 \mathrm{~cm}$ between rows. Alfalfa cultivars and experimental strains with a high proportion of falcata [M. sativa subsp. falcata (L.) Arcang.] parentage were better adapted to interseeding into rangeland at a semiarid site in the northern Great Plains than traditional hay-type cultivars which have a high proportion of sativa (M. sativa L. subsp. sativa) parentage. Sativa-types with high levels of known winterhardiness had low survival in this test. Seven years after plant establishment, the 12 falcata-type entries averaged $100 \%$ more plants or propagules $\mathrm{m}^{-2}, 124 \%$ wider foliage spread of plant rows, and $68 \%$ more dry matter yield, respectively, than the 13 sativa-type entries. Traits associated with falcata parentage such as plant spread by root proliferation and broad crown development, dormancy during midsummer drought, and slow, decumbent regrowth may help to enhance alfalfa survival in semiarid rangeland in the Northern Great Plains. These traits have no known utility in more humid environments where maximum forage yields from multiple harvests is a primary objective.
\end{abstract}

Key Words: forage, Medicago sativa L., semiarid, root proliferation, rhizome proliferation, creeping-root, pasture

\footnotetext{
Authors are research geneticist, research geneticist (retired), and plant physiologist, respectively, U.S. Department of Agriculture, Agricultural Research Service, Northern Great Plains Research Laboratory, P.O. Box 459, Mandan, North Dakota 58554. Manuscript accepted 23 January 1989.
}

The value of an alfalfa component in the rangelands and dryland pastures in the Northern Plains region of North America has been well documented (Campbell 1963, Houston and Adams 1971, Lorenz 1982). Sustained efforts have been made to develop persistent alfalfa cultivars adapted to rangeland in this region (Heinrichs 1954, Adams 1956, Rumbaugh 1982). These cultivars have resulted from hybrids [M. sativa subsp. varia (Martyn) Arcang.] between common purple-flowered alfalfa ( $M$. sativa $L$. subsp. sativa) and yellow-flowered alfalfa [M. sativa subsp. falcata (L.) Arcang.]. Cultivars adapted to rangeland in the Northern Plains have had relatively high proportions of falcata germplasm in their parentage. Oakley and Garver (1917) provided a detailed description of plant morphology and growth characteristics of falcata-type alfalfa. Heinrichs (1975) described traits obtained from falcata germplasm that have been important to survival of alfalfa in semiarid rangeland of western Canada. These include proliferation of new shoots from horizontal roots (creeping root trait), deep-set crowns that protect plants from trampling and winter injury, dormancy during long dry and cold periods, and slow regrowth after grazing. Rumbaugh and Johnson (1983) found that high seed production and seedling vigor associated with sativa germplasm were important in maintaining a stand of alfalfa by natural reseeding over a 25-year period at a semiarid site in Utah.

Traits important to survival are expressed in varying degrees among different alfalfa cultivars and strains. Expression of these traits in germplasm adapted to semiarid rangeland is often masked in standard performance tests, because these tests are seeded in narrow rows with high plant densities, in monoculture stands, often at mesic or irrigated sites, and usually are maintained for short periods ( 3 to 5 years). This study assesses survival and agronomic performance of 7 -year-old stands of 25 alfalfa cultivars and experimental strains with a wide range in genetic background and origin that were interseeded into rangeland at a semiarid site near 
Table 1. Origin of alfalfa cultivars and experimental strains interseeded into a grass sward near Mandan, ND in 1978.

\begin{tabular}{lc}
\hline \hline Cultivar or Strain & \multicolumn{1}{c}{ Origin } \\
\hline Drylander & Group I. Rhizome and root proliferation \\
\cline { 2 - 2 } Roamer & $\begin{array}{c}\text { Agriculture Canada, Swift Current, Sas- } \\
\text { katchewan, Canada } \\
\text { Agriculture Canada, Swift Current, Sas- } \\
\text { katchewan, Canada }\end{array}$ \\
Swift Current S3703L & $\begin{array}{c}\text { Agriculture Canada, Swift Current, Sas- } \\
\text { katchewan, Canada }\end{array}$ \\
Travois & $\begin{array}{c}\text { South Dakota Agric. Exp. Sta., Brook- } \\
\text { ings, SD }\end{array}$ \\
South Dakota T25SYN2 & South Dakota Agric. Exp. Sta., Brook- \\
ings, SD \\
Spredor 2 & $\begin{array}{c}\text { Northrup, King and Company } \\
\text { Alaska Synthetic A }\end{array}$ \\
Alaska Agric. Exp. Sta. and USDA-ARS, \\
Palmer, AK
\end{tabular}

Group III. Narrow crown with little rhizome proliferation

Denali

Ladak

Pioneer 520

Pioneer 524

WL220

Phytor

Baker

Dawson

Minnesota Exp 4020

Ramsey

Kansas KS-10

Kanza

Riley

Mandan, N.Dak. The relative survival and productivity of current alfalfa cultivars and experimental strains at a rangeland site will be helpful in assessing the relationship of different traits to survival and productivity and in choosing parental germplasm for a breeding program.

\section{Materials and Methods}

Twenty-five alfalfa cultivars and experimental strains (Table 1) were interseeded into rangeland near Mandan, N. Dak. on 15 May 1978. Entries in this test were classified into 3 categories as follows:
Group I-Plant spread by rhizome and root proliferation ( 8 entries); Group II-Plant spread by rhizome proliferation (4 entries); and Group III-Narrow plant crown with little rhizome proliferation (13 entries). Falcata germplasm is prevalent in the genetic background of all entries in Groups I and II. All entries in Groups I and II have a fibrous root system and a low-set crown, but their method of vegetative proliferation is different. Root proliferation, common only to entries in Group I, results from adventitious shoot propagules arising at irregular intervals on horizontal roots located 10 to $20 \mathrm{~cm}$ below the soil surface. In rhizome proliferation, new propagules are produced from short horizontal stems that arise from a low-set crown. Both root and rhizome proliferation occurred in the test environment. Entries in Group III have a high percentage of sativa germplasm in their parentage, which results in a tap or branch-root system, relatively narrow and high-set crowns, and usually more rapid regrowth after cutting or grazing than entries in Groups I and II.

Each entry was replicated 4 times in a randomized complete block design in plots consisting of 3 interseeded rows $6.1 \mathrm{~m}$ long with $90 \mathrm{~cm}$ between rows. Seeding rate was 60 pure live seeds per lineal meter of row which corresponded to approximately $1.4 \mathrm{~kg}$ $\mathrm{ha}^{-1}$ for the $90-\mathrm{cm}$ row spacing. Associated grasses consisted primarily of crested wheatgrass ,Agropyron desertorum (Fisch. ex Link) Schult.], western wheatgrass [ Pascopyrum smithii (Rydb.) Löve] Syn: Agropyron smithii (Rybd.), needle-and-thread (Stipa comata Trin. and Rupr.), and blue grama [Bouteloua gracilis (H.B.K.) Lag.]. Grass competition was reduced during alfalfa seedling establishment by sowing the alfalfa in furrows approximately $15 \mathrm{~cm}$ wide and $10 \mathrm{~cm}$ deep that were made with a custom-made implement used for interseeding research plots in grass stands. Soil was classified as a Chama silt loam (Typic Haplustolls), an upland soil with moderate water holding capacity. Annual precipitation deviated less than $10 \%$ from the long-term average of $42 \mathrm{~cm}$ in all years except 1982 when precipitation was $126 \%$ of average. March through June precipitation, which averages $20 \mathrm{~cm}$, was 44, 37, and $56 \%$ of normal for 1979,1980 , and 1981 , respectively. Plots in the study were mowed to a height of $10-15 \mathrm{~cm}$ in early September each year. Other management consisted of light grazing with cattle for a period of less than 4 weeks and/or haying once each year beginning in 1978.

Live plant numbers per plot were counted 5 May 1979 and 17 May 1980, and a combined plant and propagule total was recorded 20 May 1985. Frost injury to each plot was rated 12 May 1980 , on a scale from 0 to 9 where $0=$ no injury and $9=>90 \%$ of vegetation frost injured. Width of alfalfa plant cover, a measure of rhizome and root proliferation, was recorded 16-17 June 1985 at $60-\mathrm{cm}$ intervals along each plot row, and mean plant cover width was calculated for each plot. Flower color, as categorized by Barnes (1972), was recorded for each plot on 26 June 1985 on a scale from 1 to 5 where $1.1=$ dark purple and $4.4=$ dark yellow. On 12 July 1985 , foliage dessication was rated on a scale from 1 to 10 where $1=$ dry and $10=$ succulent, and growth habit was rated on a scale from 1 to 5 where $1=$ decumbent and $5=$ erect. Dry matter yields of alfalfa from the center row of each plot were measured $15 \mathrm{July}$ 1985 , and height of regrowth was measured 70 days past harvest on 23 September.

Data were analyzed by standard analysis of variance procedures. Means among the Group I, Group II, and Group III categories for plant stand, foliage spread, plant cover index, dry matter yield, and height of regrowth were tested for significant differences according to $\mathrm{F}$ ratios from single degree of freedom comparisons. Relationships between various traits were measured with Pearson correlation coefficients using data from all plots. 
Table 2. Plant stands of alfalfa cultivars and experimental strains interseeded into a grass sward near Mandan, ND in 1978.

\begin{tabular}{|c|c|c|c|}
\hline \multirow[b]{2}{*}{ Cultivar or strain } & \multicolumn{3}{|c|}{ Year of sampling } \\
\hline & 1979 & 1980 & 1985 \\
\hline Group I. Rhizome and root proliferation & \multicolumn{3}{|c|}{ (Plants or propagules $\left.\mathrm{m}^{-2}\right)$} \\
\hline Drylander & 6.8 & 3.9 & 7.8 \\
\hline Roamer & 6.7 & 4.2 & 4.6 \\
\hline Swift Current S3703L & 8.9 & 5.0 & 5.7 \\
\hline Travois & 7.9 & 4.8 & 5.7 \\
\hline South Dakota T25SYN2 & 7.5 & 3.9 & 4.2 \\
\hline Spredor 2 & 9.3 & 4.7 & 7.3 \\
\hline Alaska Synthetic A & 8.9 & 3.1 & 6.8 \\
\hline Mandan MAL34 & 8.9 & 4.8 & 4.3 \\
\hline \multicolumn{4}{|c|}{ Group II. Rhizome proliferation } \\
\hline Alaska Synthetic B & 8.2 & 3.9 & 4.0 \\
\hline Alaska Falcata Strain & 5.5 & 2.9 & 3.5 \\
\hline Colorado C-3 & 12.0 & 5.4 & 3.5 \\
\hline Mandan MAL33 & 6.2 & 3.3 & 5.0 \\
\hline \multicolumn{4}{|c|}{ Group III. Narrow crown with little proliferation } \\
\hline Denali & 6.4 & 3.4 & 3.4 \\
\hline Ladak & 7.0 & 3.4 & 2.7 \\
\hline Pioneer 520 & 10.0 & 4.6 & 3.2 \\
\hline Pioneer 524 & 5.9 & 2.7 & 1.6 \\
\hline Waterman-Loomis 220 & 10.2 & 5.7 & 4.0 \\
\hline Phytor & 9.5 & 4.6 & 2.4 \\
\hline Baker & 6.2 & 3.5 & 2.2 \\
\hline Dawson & 7.4 & 2.9 & 3.0 \\
\hline Minnesota Exp 4020 & 6.2 & 3.2 & 2.4 \\
\hline Ramsey & 5.7 & 3.0 & 2.6 \\
\hline Kansas KS-10 & 7.3 & 4.6 & 3.3 \\
\hline Kanza & 8.2 & 4.4 & 1.3 \\
\hline Riley & 6.6 & 3.4 & 1.8 \\
\hline SEM & 1.3 & 0.7 & 0.9 \\
\hline L.S.D. .00 & 3.8 & 2.1 & 2.6 \\
\hline Mean Group I & $8.1^{\text {a1 }}$ & $4.3^{\mathrm{a}}$ & $5.8^{\mathrm{a}}$ \\
\hline Mean Group II & $8.0^{\mathrm{a}}$ & $3.9^{\mathrm{n}}$ & $4.0^{b}$ \\
\hline Mean Group III & $7.4^{a}$ & $3.8^{\mathrm{a}}$ & $2.6^{\mathrm{e}}$ \\
\hline
\end{tabular}

IGroup means within each year followed by a different letter differ $(P<0.01)$ according to $F$ ratios from single degree of freedom comparisons.

\section{Results and Discussion}

No differences in plants $\mathrm{m}^{-2}$ were found among overall means for Groups I, II, and III in the first 2 years following establishment (Table 2). Stand density declined sharply from 1979 to 1980 for all entries, indicating that plant counts made 1 year after establishment did not provide a reliable estimate of long-term stand density. In 1985, 7 years after establishment, all but 1 of the alfalfa entries in Group I had increased in stand density compared with 1980; densities of most of the entries in Group II had remained static while most of the entries in Group III had declined. Group I, which contained entries that spread by a combination of root and rhizome proliferation, had higher mean stand densities in 1985 than Groups II and III $(P<0.01)$. Even with relatively low levels of defoliation stress from grazing and cutting, most of the traditional hay-type cultivars in Group III did not have adequate persistence. Hay-type cultivars noted for high levels of winterhardiness ('Denali', 'Ladak', 'Ramsey') had relatively low survival, which is in agreement with a previous grass-alfalfa grazing study conducted with yearling ewes at Mandan (Berdahl et al. 1986). Thus, while high levels of winterhardiness in alfalfa are needed in northern climates, other traits such as vegetative proliferation from roots and rhizomes also appear to be important to survival in rangeland in the Northern Plains. Injury or death of the original crown from pocket gopher activity appeared to stimulate production of new propagules in Entries that spread by root proliferation.
Table 3. Foliage spread of plot rows and percentage of measurements within 3 foliage spread categories on 12 July 1985 for 25 alfalin cultivars and experimental strains interseeded into grass sward near Mandan, ND in 1978.

\begin{tabular}{|c|c|c|c|c|}
\hline \multirow[b]{2}{*}{ Cultivar or strain } & \multirow{2}{*}{$\begin{array}{l}\text { Mean } \\
\text { foliage } \\
\text { spread }\end{array}$} & \multicolumn{3}{|c|}{$\begin{array}{l}\text { Percentage within each } \\
\text { foliage spread category' }\end{array}$} \\
\hline & & $0-25 \mathrm{~cm}$ & $26-50 \mathrm{~cm}$ & $>50 \mathrm{~cm}$ \\
\hline \multicolumn{5}{|c|}{$(\mathrm{cm})$} \\
\hline \multicolumn{5}{|c|}{ Group I. Rhizome and root proliferation } \\
\hline Drylander & 58 & 16 & 24 & 60 \\
\hline Roamer & 34 & 52 & 29 & 19 \\
\hline Swift Current S3703L & 44 & 27 & 45 & 28 \\
\hline Travois & 40 & 25 & 48 & 27 \\
\hline South Dakota T25SYN2 & 25 & 65 & 29 & 6 \\
\hline Spredor 2 & 53 & 16 & 42 & 42 \\
\hline Alaska Synthetic A & 47 & 12 & 50 & 38 \\
\hline Mandan MAL34 & 42 & 27 & 43 & 30 \\
\hline \multicolumn{5}{|c|}{ Group II. Rhizome proliferation } \\
\hline Alaska Synthetic B & 24 & 62 & 38 & 0 \\
\hline Alaska Falcata Strain & 32 & 38 & 55 & 7 \\
\hline Colorado C-3 & 28 & 60 & 35 & 5 \\
\hline Mandan MAL33 & 25 & 67 & 28 & 5 \\
\hline
\end{tabular}

Group III. Narrow crown with little rhizome proliferation

\begin{tabular}{lcrrr} 
Denali & 22 & 76 & 24 & 0 \\
Ladak & 18 & 87 & 13 & 0 \\
Pioneer 520 & 19 & 83 & 16 & 1 \\
Pioneer 524 & 19 & 77 & 21 & 2 \\
Waterman-Loomis 220 & 19 & 86 & 14 & 0 \\
Phytor & 16 & 82 & 14 & 4 \\
Baker & 18 & 83 & 17 & 0 \\
Dawson & 16 & 91 & 7 & 2 \\
Minnesota Exp 4020 & 17 & 87 & 13 & 0 \\
Ramsey & 15 & 95 & 5 & 0 \\
Kansas KS-10 & 17 & 95 & 4 & 1 \\
Kanza & 14 & 93 & 7 & 0 \\
Riley & 14 & 88 & 12 & 0 \\
$\quad$ SEM & 3.7 & & & \\
$\quad$ L.S.D. 05 & 10.9 & & & \\
$\quad$ Mean Group I & $42.8^{\mathrm{a} 2}$ & & & \\
Mean Group II & $27.2^{\mathrm{b}}$ & & & \\
Mean Group III & $17.3^{\mathrm{b}}$ & & & \\
\hline
\end{tabular}

'Percentages based on sampling sites with live plants from a total of 108 sites per entry. ${ }^{2}$ Group means followed by a different letter differ $(R<0.01)$ according to $\mathrm{F}$ ratios from single degree of freedom comparisons.

Group I exhibited the widest foliage spread and, among Group I cultivars and strains, 'Drylander' had the greatest spread and the highest percentage of spread measurements exceeding $50 \mathrm{~cm}$ (Table 3). South Dakota T25SYN2, an experimental strain selected for low bloat properties from the cultivar 'Travois' (A.A. Boe, 1987, personal communication), had the narrowest foliage spread of entries in Group 1. The decrease in foliage spread of South Dakota T25SYN2 relative to Travois $(P<0.01)$ illustrates that genes controlling the expression of root proliferation may be lost if selection for plant spread is not maintained in selection programs for other traits.

Entries in Group II had a high percentage of falcata germplasm in their parentage and had intermediate foliage spread as a result of rhizomatous spreading (Table 3). Heinrichs (1954) reported that the rhizomatous alfalfa cultivars 'Rhizoma' and 'Nomad' did not spread to any extent in arid prairie regions of Canada. He observed that rhizomatous spread occurred most rapidly when the surface soil was moist for prolonged periods, particularly in the fall season. On the other hand, spread by root proliferation can occur under dry soil conditions.

Alfalfa dry matter yields were measured only in 1985 and were subject to relatively high experimental error $(C . V .=25.1 \%)$. Even though 1 year's yield data were not adequate to statistically separ- 
ate the means of individual alfalfa entries, some general trends were observed. Low numbers of surviving plants (Table 2) and a low plant cover index (Table 4) contributed to low dry matter yields of traditional hay-type cultivars that constituted Group III.

Table 4. Mean plant cover indices, dry matter yields, and fall regrowth in 1985 for 25 alfalfa cultivars and experimental strains interseeded into a grass sward near Mandan, ND in 1978.

\begin{tabular}{lcccc}
\hline \hline $\begin{array}{l}\text { No. } \\
\text { Cultivar and strain group }\end{array}$ & $\begin{array}{c}\text { Plant } \\
\text { cover } \\
\text { index }\end{array}$ & $\begin{array}{c}\text { Dry } \\
\text { matter } \\
\text { yield }\end{array}$ & $\begin{array}{c}\text { Fall } \\
\text { regrowth }\end{array}$ \\
\hline & & & $\left(\mathrm{g} \mathrm{m}^{-2}\right)$ & $(\mathrm{cm})$ \\
$\begin{array}{l}\text { I. Rhizome and root pro- } \\
\text { liferation }\end{array}$ & 8 & $987^{\mathrm{as}}$ & $497^{\mathrm{a}}$ & $10.4^{\mathrm{b}}$ \\
$\begin{array}{l}\text { II. Rhizome proliferation } \\
\text { III. Narrow crown }\end{array}$ & 4 & $573^{\mathrm{b}}$ & $420^{\mathrm{b}}$ & $11.1^{\mathrm{b}}$ \\
$\quad 13$ & $277^{\mathrm{c}}$ & $280^{\mathrm{c}}$ & $14.4^{\mathrm{a}}$ \\
$\quad$ Overall mean (n=25) & & 551 & 372 & 12.6 \\
\hline
\end{tabular}

IPlant cover index $=$ mean row width $X$ number of sites at $60 \mathrm{~cm}$ intervals within plot rows that contained live alfalfa plants.

${ }^{2}$ Fall regrowth $=$ Plant height 70 days following 15 July 1985 harvest.

${ }^{3}$ Means followed by a different letter differ $(P<0.01)$ according to $\mathrm{F}$ ratios from single degree of freedom comparisons.

In 1985, correlation coefficients were $0.77(P<0.01)$ between dry matter yield and plant stand and $0.79(P<0.01)$ between dry matter yield and plant cover index. Seven years past establishment, no entry in Group III ranked above any of the entries in Groups I and II for single-cut yield of dry matter. The $90 \mathrm{~cm}$ row spacing in this study may have contributed to high forage yields of falcata types relative to sativa types. Irvine and Jefferson (1984), at a dryland site near Swift Current, Saskatchewan, found that a $30-\mathrm{cm}$ row spacing favored high yields of sativa-type cultivars, while a $90-\mathrm{cm}$ spacing favored high yields of falcata-type cultivars.

Plant height measured 70 days past the 15 July 1985 harvest indicated that the 13 hay-type cultivars in Group III had greater fall regrowth than entries in Groups I and II (Table 4). Regrowth of alfalfa utilizes carbohydrate root reserves (Smith 1972), and slow regrowth may contribute to maintenance of root reserves and greater persistence. In a previous study at Mandan (Berdahl et al. 1986), alfalfa cultivars and strains with fast regrowth potential had poor persistence under grazing stress.

Heinrichs (1975) concluded that dormancy during extended periods of drought was an important survival mechanism that contributed to persistence of pasture-type alfalfas in semiarid climates. Differences in degree of wilting among entries in this test during hot, dry periods in midsummer suggested that the entries differed in their capacity to go dormant under drought stress. Dessication was visually rated on 12 July 1985 to obtain a measure of drought-induced dormancy. Dessication scores averaged 5.9 for pasture-type cultivars and strains in Groups I and II and significantly more succulent $(P<0.01)$ at 6.9 for hay-type cultivars in Group III. Dry matter percentages of harvested forage, a more precise measure of plant dessication, were significantly higher $(P<0.01)$ by $4.3 \%$ for entries in Groups I and II than for Group III. A correlation coefficient of 0.63 between visual desiccation scores and dry matter percentages, although significant at $P<0.01$, was only moderately high and indicated that visual dessication scores did not provide a precise measure of the degree of drought-induced dormancy. Nevertheless, the falcata-type entries in Groups I and II were dormant to some extent during periods of drought while sativa-types in Group III had turgid leaves and appeared to be actively growing. During extended periods of drought, the nondormant sativa-type alfalfas have a deeper root system than falcata-types and have the potential to deplete soil water to greater depths in the soil profile (Garver 1922). Soil water depletion from sativa-types may be detrimental to associated grass species and, ultimately, to the alfalfa component itself if the soil profile is not recharged with water.

Additional measurements were made to categorize various traits. Frost injury after a $-6.1^{\circ} \mathrm{C}$ minimum temperature on 8 May 1980 was lowest for entries in Groups I and II with a falcata genetic background, particularly experimental strains from Alaska. Alaska Synthetic A, Alaska Synthetic B, 'Alaska Falcata', and Mandan MAL 34 all had less than $10 \%$ frost injury to spring foliage growth, while 'Phytor', 'Kanza', and 'Baker' were highest, averaging 40 to 50\%. Yellow flower pigmentation from $M$. sativa subsp. falcata (L.) Arcang. and purple pigmentation from $M$. sativa $L$. subsp. sativa have been used to estimate the relative amounts of falcata and sativa germplasm within different alfalfa populations. According to a scale proposed by Barnes (1972), flower color varied among entries from 1.3 (light purple) for Ramsey to 4.3 (dark yellow) for Alaska falcata. However, some entries such as 'Spredor 2' with a high proportion of falcata parentage had light purple flower color. Introgression of traits from falcata to sativa germplasm is complex, and no single trait provides a reliable indication of the amount of falcata or sativa germplasm in a population. Decumbent growth habit or other traits from falcata associated with decumbent growth habit may have been beneficial in this interseeded study. Growth habit score (1=decumbent, 5=erect) averaged 2.4 for the 12 pasture-type cultivars and strains in Groups I and II and significantly higher $(P<0.01)$ at 4.0 for the 13 hay-type cultivars in Group III. Denali from Alaska, the most decumbent and highest yielding of the hay-type cultivars, had a growth habit score of 3.0. In 1985, scores for erectness of growth had correlation coefficients of $-0.54(P<0.01),-0.70(P<0.01)$, and $-0.60(P<0.01)$ with plants or propagules $\mathrm{m}^{-2}$, plant cover index, and dry matter yield, respectively.

\section{Conclusions}

Alfalfa cultivars and experimental strains with a high proportion of falcata parentage were better adapted to interseeding into rangeland at a semiarid site in the northern Great Plains than traditional hay-type cultivars which have a high proportion of sativa parentage. Seven years after establishment, falcata types were highly superior to sativa types in survival and forage yields from a single, mid-July harvest. Plant spread from root proliferation and broad crown development from rhizome proliferation were associated with high survival and high forage yields. Sativa types with high levels of known winterhardiness had low survival in this test. Other traits associated with falcata parentage such as dormancy during midsummer drought and slow, decumbent regrowth may enhance alfalfa survival in semiarid rangeland in the Northern Great Plains but may have no utility in more humid environments where maximum forage yields from multiple harvests is a primary objective.

\section{Literature Cited}

Adams, M.W. 1956. Creeping alfalfa. South Dakota Farm Homes Res. 7:74-77.

Barnes, D.K. 1972. A system for visually classifying alfalfa flower color. USDA-ARS. Agricultural Handbook No. 424.

Berdahl, J.D., A.C. Wilton, R.J. Lorenz, and A.B. Frank. 1986. Alfalfa survival and vigor in rangeland grazed by sheep. J. Range Manage. 39:59-62.

Campbell, J.B. 1963. Grass-alfalfa versus grass-alone pastures grazed in a repeated-seasonal pattern. J. Range Manage. 16:78-81.

Garver, S. 1922. Alfalfa root studies. USDA, Bur. Plant Indust. Bull. 1087.

Heinrichs, D.H. 1954. Developing creeping-rooting alfalfa for pasture. Can. J. Plant Sci. 34:269-280.

Heinrichs, D.H. 1975. Potentials of legumes for rangelands, p. 50-61, In: R.S. Campbell and C.H. Herbel (ed.). Improved Range Plants. Range Symposium, Series 1. Soc. Range Manage., Denver, Colo. 
Houston, W.R., and R.E. Adams. 1971. Interseeding for range improvement in the Northern Great Plains. J. Range Manage. 24:457-461.

Irvine, R.B., and P.G. Jefferson. 1984. Alfalfa (Medicago sativa L. and $M$. falcata $L$.) cultivar $X$ row spacing interaction on yield at a semiarid environment in southwestern Saskatchewan. Can. J. Plant Sci. 64:895900.

Lorenz, R.J. 1982. Alfalfa in western grazing management systems, p. 1-3. In: Alfalfa for dryland grazing. USDA-ARS. Agr. Infor. Bull. 444.

Oakley, R.A., and S. Garver. 1917. Medicago falcata, a yellow-flowered alfalfa. USDA, Bur. Plant Indust. Bull. 428.
Rumbaugh, M.D. 1982. Origins of alfalfa cultivars used for dryland grazing, p. 15-19. In: Alfalfa for dryland grazing. USDA-ARS. Agr. Inform. Bull. 444.

Rumbaugh, M.D., and D.A. Johnson. 1983. Changes in alfalfa cultivars grown in a semiarid environment. Crop Sci. 23:477-480.

Smith, D.1972. Cutting schedules and maintaining pure stands, p. 481-496. In: C.H. Hanson (ed.). Alfalfa science and technology. Agron. Mono. 15. Amer. Soc. Agron., Madison, Wisc. 